\title{
Improving Beginning Mathematical Skills Through Problem Solving Approach
}

\author{
Setiyo Utoyo \\ Early Childhood Teacher Education Departement, \\ Universitas Negeri Gorontalo \\ Email: setyo.utoyo@gmail.com
}

\author{
Ismaniar \\ Department of Non Formal Education \\ Faculty of Education Universitas Negeri Padang \\ Email: ismaniar.js@gmail.com \\ indriyanabk@gmail.com
}

\begin{abstract}
The aim of this research is to improve the mathematical ability the young children through the problem solving approach. The subject of this research were kindergarten students of Graup B Al Hikmah Bintara Kindergarten of West Bekasi. The method used in this research was action research. In which, the procedure of the research were consisted of fair step us followed model by Kemmis and Mc Taggarct's which was modified by Martini Jamaris. The model of this research is in: a). planning, b) action, c) observation, and d) reflection. The data collection was conducted through observation, assessment, document analysis and voice or picture recording. The data were analyzed by using quantitative and qualitative analysis. The result of the reseach showed that the mathematical skills of the young children were increased it was prowed by both the first and second cycle assessment of the contain aspects of mathematical skills. The conclusion of this research is by using a problem solving approach can significantly increase yaung children's' mathematical skills.
\end{abstract}

Keywords-beginning mathematical skills; problem solving approach

\section{INTRODUCTION}

One aspect of improvement of cognitive ability of children is by optimizing the ability of math in early childhood. Through the learning of mathematics from an early age it will introduce the child to the ability and skills in order to understand all the concepts of mathematical recognition as a science and build a systematic and objective scientific mindset and equip process skills through scientific methods or research.

If stimulation is done with the right approach and supported by a conducive environment of early childhood, especially kindergarten age (5-6 years) should have been able to master the ability of math (classify, sort, match, geometry, number concept, and number operations). This is in accordance with curriculum standards set forth in NCTM (2000 National Council of Teachers of Mathematics).

The result of the interview with the group B teacher (Sumiyati, SPd,) TK Al Hikmah Bintara Bekasi Barat on November 7, 2011 revealed that there are still many children who have not developed the ability of mathematics, this is seen from the work sheet of children every day. For more details the initial evaluation results on the ability of matematika early child kindergarten Al Hikmah can be seen in the following table;

\begin{tabular}{|c|c|c|c|c|c|c|}
\hline \multirow[t]{2}{*}{ No. } & \multirow[t]{2}{*}{ Observed Aspects } & \multicolumn{4}{|c|}{ Math Capability } & \multirow[t]{2}{*}{ Description } \\
\hline & & Good & Quita & Les: & $\begin{array}{l}\text { Number of } \\
\text { Children }\end{array}$ & \\
\hline 1 & Classifying & 6 & 6 & 8 & 20 & \\
\hline 2 & Sorting & 5 & 7 & 8 & 20 & \\
\hline 3 & Match & 5 & 6 & 9 & 20 & \\
\hline 4 & Geometry & 4 & 4 & 12 & 20 & \\
\hline 5 & Concept mumbers & 2 & 6 & 12 & 20 & \\
\hline 6 & Operation mumber & 2 & 8 & 10 & 20 & \\
\hline \multicolumn{2}{|c|}{ Average } & $20 \%$ & $30,8 \%$ & $49,2 \%$ & $100 \%$ & \\
\hline
\end{tabular}

Table 1. Data from Daily Activities Plan (RKH) TK Al Hikmah Bintara Bekasi Semester I

The table above shows that the mathematical ability of children in Group B TK Al Hikmah Bintara Bekasi Barat is generally still in less category. This is allegedly due to the inability of teachers in a variety of learning approaches, innovative and even among teachers rather rigid in the learning process. In addition, in learning less mathematics using a variety of media or a simple way of solving problems that can be understood children, easy and fun, of course children happy according to the principle of learning while playing.

This study offers an approach that is expected to help change as well as improve the quality or quality of education, especially pengusaan field of mathematics development.The mathematics learning approach that is done through problem solving approach. From the background, the researchers are interested to make further observations about the process of learning activities in early childhood, especially children of kindergarten age in order to recognize, understand and master the field of development of mathematics. Through action research or action research in the process of learning mathematics through how to apply problem solving approach it is expected to be able to improve and improve learning outcomes mathematical knowledge in early childhood to be more optimal. 


\section{Research Focus}

This research is focused on the use of problem solving approach in improving early math skills in kindergarten children of B ages 5 to 6 years.

\section{Formulation of Research Problems}

The formulation of research problems as follows:

a. How to prepare learning activities to improve early mathematical skills through problem solving approach in kindergarten children B group?

b. How does the process of implementing learning activities to improve early math skills through problem solving approach?

c. How to evaluate the achievement of early mathematical skills through problem solving approach?

d. How does the improvement of prior mathematical skills before and after the action through problem solving approach?

\section{THEORETICAL STUDY}

\section{Concept of Action Research}

Stephen Kemmis in [1] says that action research is a form of self-reflection conducted by participants (teachers, students, principals) in social situations (including education) to improve the rationality of truth between: a) their own social and educational practices, b) an understanding of such practices, c) the circumstances in which they are exercised.

John Elliot in [1] argues that action research is a study of the social situation with the aim of improving the quality of action both in practical situations, concrete situations, and the vali- tations of 'theory' or the hypothesis is not much dependent on scientific truth, as in its usefulness in helping people to act intelligently and skillfully. In theory action research is not validated practically. In practice this action research helps self-improvement of teachers in their teaching and learning activities.

The action research is a program plan designed on the basis of plans developed, discussed between researchers, collaborators, and teachers or classroom teachers. This action research is participatory and collaborative [2]. This means that action research is investigated by researchers and teachers to work together (collaborators) in conducting action research in the classroom. Furthermore, the matters related to the action program will be discussed after the initial condition of the research

Thus, it can be concluded that action research is 1) a selfreflection of teachers in improving the quality of learning, 2) systematic study in improving education practice, 3) social situation in improving the quality of action, 4) a combination of quantitative and qualitative research so that it has both types of data 5) and participatory action research and collaborators.
The research model of action that the author thoroughly uses the Kemmis and Taggart model is spiral action research from the preparation of the planning, the implementation of tinda, observation (observation), and reflection followed by the next spiral cycle.

\section{Initial Mathematical Capability}

The ability is the mental and physical capacity to perform various tasks [3]. While the characteristics of early mathematical abilities according to NAEYC'S mathematics for children include numbers and number operations, patterns, functions and algebra, geometry, space, size, and data analysis, and opportunities [4]. The mathematical concepts studied by children are: classification, matching, pattern, and algebraic thinking, measurements, numbers and number operations, time, geometry and space, form, show and analyze data [5].

NCTM 2000 in [6] the standard of mathematics for kindergarten children up to grade 3 there are twelve standard mathematical content abilities namely: mathematics as a way of solving problems, mathematics as a way of communication, mathematics as a way of thinking, mathematical relationships, estimation and number, whole and part, count and space, measurement, pattern, statistic, and decimal. And there are five process standards: problem solving, consideration and evidence, communications, relationships and refresentation.

Mercer and Reid in [7] Early mathematics of early childhood includes 1) the ability to explain the characteristics of an object or set of objects based on the characteristics it possesses, 2) the ability to classify (classification), 3) the ability to sort objects (ordering ), 4) one-to-one matching, 5) joining, 6) separation, 7) understanding of conservation concepts.

The mathematical concepts that can be developed for early childhood include: 1) the ability to match, 2) the ability to classify, 3) the ability to compare, 4) the ability to sort things (ordering), and 5) the ability to create patterns (seriation) [8].

Thus, it can be concluded from the above opinion that the mathematical ability of the beginner is the ability of the child obtained from various processes. Mathematical ability can be applied in the form of concepts to solve the problems embodied in knowledge such as: classification, sorting objects, matching, geometry, number concepts, number operations.

\section{Problem Solving Approach}

The problem solving approach is often used in different fields of science and has different perceptions as well. According to Branca who dikutif Sumardyono, 2010 in general there are three kinds of interpretation of the term problem solving approach in the learning of mathematics, namely (1) problem solving as a goal, (2) problem solving as a process (as a process), and (3) problem solving as basic skill (as a basic skill)

a. Problem solving as goal (problem solving as a goal)

Educators, mathematicians, and those concerned with mathematics education often set problem solving as one of the goals of mathematics learning. If the problem solving 
approach is defined or regarded as a teaching objective then it does not depend on a particular problem or problem, procedure, or method, as well as the content of mathematics. An important assumption in this regard is that learning on how to solve problems (solve problems) is the "primary reason" (primary reason) to learn mathematics.

b. Problem solving as a process (problem solving as a process)

The problem solving approach is as a dynamic process. In this aspect, problem solving approaches can be used as a process of plotting all knowledge possessed in new and unusual situations. In this interpretation, what needs to be considered are the methods, procedures, strategies and heuristics that students use to solve a problem. This process problem is very important in learning mathematics and this is often the focus in the mathematics curriculum.

c. Problem solving as a basic skill (problem solving as a basic skill)

Problem solving as a basic skill goes beyond just answering the question: what is a problem solving? The role of a teacher is to exert all his or her ability to build students' ability to solve problems. Because consciously or not students every day are always faced with a problem because early learning problem solving is needed so that students can solve the problems of life in a broad and narrow sense. [9] For that problem solving approach as basic skills skill) is a basic skill that must be owned by students. Moreover, the competencies needed to face the increasing global challenges, one of them the ability to solve problems.

There are three main features of the problem solving approach:

1) Problem solving is a series of learning activities, meaning that in the implementation of problem solving there are a number of activities that must be done by the students. Problem solving does not expect students to simply listen, record, and then memorize the subject matter, but students actively think, communicate, search and process data, and finally conclude.

2) Activity learning directed to solve the problem. Problem solving puts the problem as the key of the learning process. That is, without problems then there can be no learning process.

3) Problem solving is done by using the approach of thinking scientifically through deductive and inductive thinking processes. This thinking process is done systematically and empirically. Systematic means scientific thinking is done through certain stages, while empirical means the process of completion [10].

Thus in the learning activities through problem solving approach, it is expected that teachers to encourage students and given the widest opportunity to take the initiative and think systematically in the face of a problem by applying the knowledge gained previously.

\section{Theoretical Framework}

Based on the theoretical studies described above, a theoretical framework can be developed to obtain a temporary answer to the errors that arise. More details can be illustrated as follows:

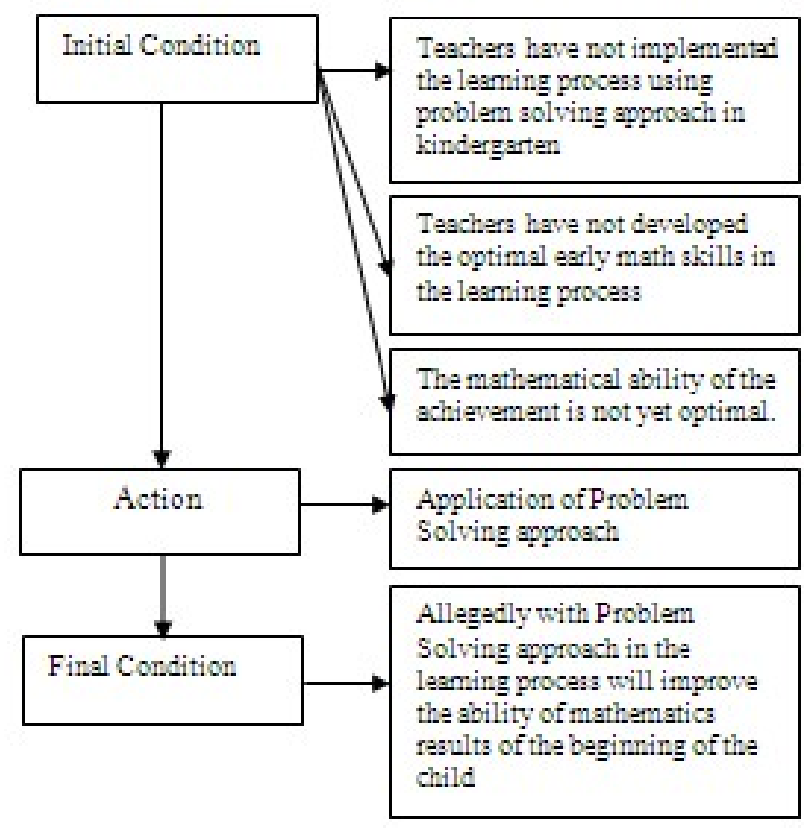

Figure 1. Theoretical Framework

\section{RESEARCH METHODOLOGY}

The research method used in this research is action research or in other words action research. According to [11] action research is reflective research by performing certain actions, in order to improve or improve the practice of classroom learning in a professional manner

McNiff explains that the goal of action research is to improve or improve the practice of learning more effectively. [1] argues that one of the strategic ways for teachers to improve or improve educational services in the context of classroom learning to carry out action research. So the goal of action research is to develop new skills or new approaches to solve immediate problems through the implementation of classroom learning. Thus based on the above description can be explained that action research aims to improve or improve a state of the learning process.

\section{RESEARCH RESULT AND DISCUSSION}

\section{Research Result}

a. Description of Initial Assessment Data

At the beginning of the study carried out the initial assessment aimed to determine the initial conditions of the child's abilities. To find out data on initial assessment of early 
math skills before action is done, it can be seen through the data presented in the following graph;

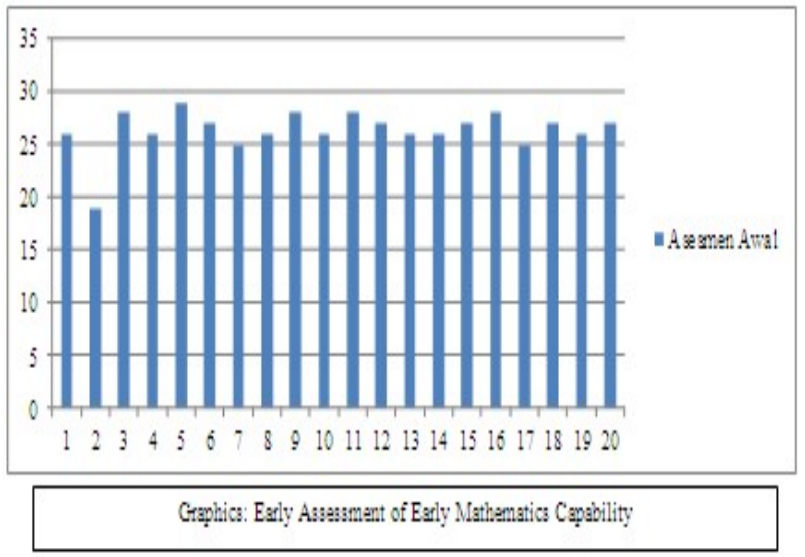

Chart 1. Asesment Pre Action

Based on the description shown in the graph above, this initial assessment result indicates that the ability of the child in performing mathematics has obtained a good result but in terms of learning is not optimal yet. Thus the initial assessment result obtained is the basis of the researcher to apply the research cycle I.

b. Description of Results of Implementation of Cycle I

Based on the results of the process of learning early math skills through problem solving approach in cycle I can be described that quantitatively has achieved good results.

For more details, the graphics of early math skills improvement after the execution of cycle I ends can be seen in the following graph:

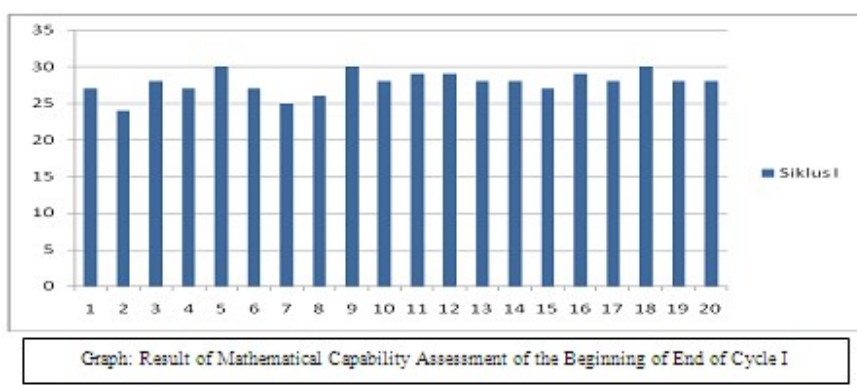

Chart 2. Action cycle 1

The graph above shows that of the 20 children who followed the final test performance of the first cycle, there were three children who scored very well (criterion 3 ). The remaining seventeen children scored well (criterion 2) and approached perfect / perfect while no more children were found to score less (criterion 1), thus improving mathematics abilities compared with achievement of preliminary results. With the average child's mathematical ability to score 27.8 and the final average of 2.78. This indicates an increase but the expected target has not been reached then continued in cycle II. c. Description of the Results of Implementation of Cycle II To see a clearer picture of the results of the performances of the mathematical skills of the aegis after the implementation of cycle II can be seen in the following graph:

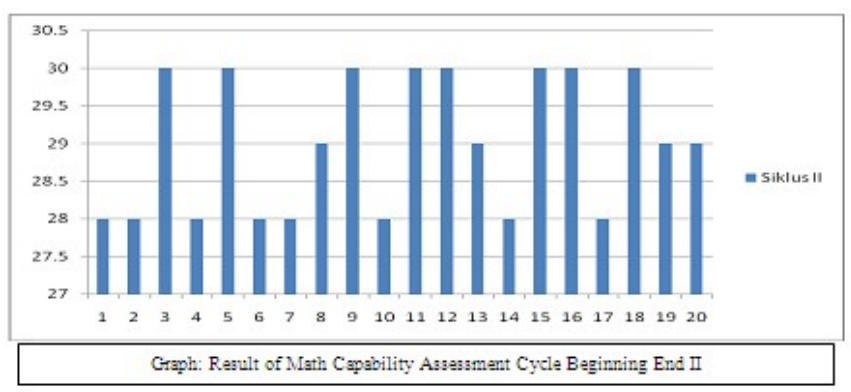

Chart 3. Action cycle 2

The graph above shows that of 20 children who scored very well (criterion 3 ) in performing performance test of final math ability mathematics cycle II there were 8 children, and all children showed improvement of mathematical ability different with the result the first cycle assessment or the initial test. Characterized by the average mathematical ability of children score 29 and the average end of 2.9 whereas if the results seen by each child no one is below 2.8. Means the study of this action is stopped in the second cycle because the overall has reached the target expected in the study.

\section{Discussion}

a. Preparation of learning problem solving approach can improve early math skills in kindergarten children

For the implementation of learning activities with this problem solving approach, the existence of the preparation stage is absolutely necessary. The important components that must exist when preparing the learning activities with problem solving approach that is; 1) determine the target of the competencies to be achieved, 2) design the learning activities, and 3) schedule the learning activities.

The learning process of problem solving approach can improve early mathematical ability in kindergarten. The process of implementing learning enhances early math skills through problem solving approach, generally designed in the form of learning with the steps of opening, presentation (core activities) and cover. In the process of implementation of learning, researchers play an active role in the implementation of activities. Since the problem solving approach is not yet familiar to both the child and the teacher, intensive observation by the researcher accelerates the discovery of any weaknesses or deficiencies found in the process. The weaknesses that occur in the implementation of the action cycle I, as well as delivery of the prologue before the child is working perform the given task. After the researcher gave input to the teacher about how to technically convey the prologue, it turns out that in cycle II can be done well.

So also with the openness of teachers in accepting children's differences in problem solving and answering the 
question of children, in the implementation of cycle I teachers seem rigid and less flexible to make children less motivated to follow the activities. But based on careful attention, as well as re-reflection with the collaborators team, various improvements can be made in cycle II.

b. Authentic assessment / observation and portfolio assessment can improve early math skills in kindergarten children

The cornerstone of developing the use of authentic assessment / observation and portfolio assessment is based on the behavior and attitude of the child in following the lesson. As a child is directly involved in learning activities eg to express his courage to make observation, investigation, ask, opinion, active, creative and critical thinking become mentradisi in the learning process.

Authentic assessment / observation and portopolio assessment are believed to be concrete results for the learning process assessment approach lies in the individual / classroom teacher, since the relationship between learning and assessment activities will be reinforced as a consequence of the continuous accumulation of the child's true capability in the form of a portfolio they. Ideally teachers who adopt portfolios in the classroom, they will make sustainable collection and assessment of the work of the children as the central focus of the teaching program, so the portfolio should be used continuously not only at the end of the period or at any given time. Portfolios are activities that actively involve children in collecting their work (document documents) to convince su- pervisors, teachers and parents of children, that something good has gone on in the classroom.

c. Problem solving learning approach can increase the activity and learning outcomes of kindergarten children

Applying the problem solving approach in the learning activities of mathematics will improve the creativity of children in learning, because indirectly will bring various changes in the learning environment and teachers. That factors that can improve the creativity of children in solving problems are seen from the aspects of the learning environment and teachers, among others: providing a learning environment that encourages children's freedom of expression, appreciate the child's questions and ideas, allowing the child to seek and find solutions in his own way, assess the originality of the child's ideas and encourage cooperative learning that develops the creativity of problem-solving.

This is evident from the results of the second cycle assessment, based on the reflection of the results of the first cycle assessment, teachers try to improve the implementation of learning by providing a clearer prologue before the child does the assigned task. As a result all children showed excellent improvement in mathematical skills. The average of the initial assessment result 2.64 rose to 2.78 in the first cycle and to 2.9 in cycle II. While the results achieved by each respondent in cycle II no longer exist under 2.8 .

Increased learning outcomes that occur can be said to be reasonable because by providing opportunities and the widest space for children to develop critical and unique knowledge, then learn more meaningful. So when the child does the performance test (math ability) then easily and able to recall the knowledge of the child's possession.

\section{Limitations of Research}

Although this research has been designed on the basis of relevant theoretical studies, there are still limitations on implementation that need attention:

a. The performance of initial mate-matic ability for kindergarten children studied in this study is limited to the ability to classify, sort, match, geometry, number concept and number operations. It is possible that more developed indicators will be adapted to the characteristics of the development of children in each school.

b. Problem solving as a process, and problem solving as a basic skill (as a basic skill). However, in this research the problem solving approach used is emphasized in problem solving as a process. While the results achieved by children is the impact of the success of learning process using problem solving approach.

c. Basically problem solving approach is a form of learning approach that requires analysis of high-level thinking. However, because in this study only in the introduction stage for early childhood, the educator needs to modify so that it can be accepted by the child. This is done in a way that the preamble begins with the prologue. As for the prologue here is an attempt to lead the thoughts or perceptions of children to enter in situations or problems that they solve.

\section{CONCLUSIONS AND SUGGESTION}

\section{Conclusion}

Based on the findings and discussion, this study concludes as follows:

a. Preparation of learning of the ability of the mathematics of the problem solving technique is done in the form of learning activities by using performance test and observation with the target ability to classify (grouping objects based on color, size and shape), sort (pattern size), geometry (the introduction of basic geometric shapes), the concept of numbers (counting 1-20 and the other way around, the concept of numbers by the number symbol), number operations (summing with objects 1-20, subtracting with objects 1-20)

b. The process of problem solving learning approaches to improve math skills is initiated, designed and based on the curriculum of KTSP that adaptation or revision to aspects of harmonizing the implementation procedures, learning scenarios, child worksheets and simplification of processing instruments data in the form of a learning activity unit.

c. An evaluation system using authentic assessment / direct observation and portfolio assessment can improve the 
child's learning level controllable and programmed, especially in the performance of early mathematical skills. The process of recording the data, the observation/observation in depth towards the students is done continuously (not the momentary portrait) individually or the working group of children, so that can know the clear picture about the student's learning progress in the learning process, through the ability to solve the problem, critical thinking, quiz and math test assessments. This situation causes students to be challenged in arguing, critical thinking, problem solving to become a tradition, and courage in exploring his or her knowledge. In other words, through problem solving learning, it can bridge the child to be more motivated in digging his ability to develop and increase and the availability of adequate tools/resources as a result of the application of observation and ases-men portopolio.

d. Implementation of early learning mathematics in kindergarten children through problem solving approach can increase the activity and learning outcomes of children optimally. From the results of the initial assessment the average mathematical ability of children 2.64 increased significantly at the end of the first syllabus to 2.78 . Furthermore, a remarkable improvement also occurred at the end of cycle II, the result of the assessment showed the average mathematical ability of children reached 2.9. Improved early math skills can also be seen from an increase in score on each item or from a score of mathematical ability of the beginning of each child / respondent. This is as a result of the application of problem solving approach to give the widest opportunity to the students to solve learning problems such as challenged children, observation, investigation, experiment, mathematical ability, discussion and presentation, report his work either verbally or in his work so that learning becomes meaningful and fun.

\section{Suggestion}

Based on the conclusions and implications of the above research, it can be suggested as follows:

a. For Educators / Teachers PAUD

In relation to the application of learning through the approach of problem solving, it is suggested to consider the following:

1) Choosing a learning approach oriented to the center and interest in learning of children one of the learning with problem solving approach.

2) Using varied learning backgrounds both in class and outside the classroom.

3) Treat children as learning subjects in the context of active, independent, or collaborative learning.

4) Accessing the knowledge and experience of the child into the learning process so that students can solve the problem of learning problems in every aspect of development, of course, in the ability of early childhood mathematic.

b. PAUD Organizer / Operators
Management of static classroom management as it happens in kindergarten needs to be changed into a dynamic class, conducive and fun in the application of problem solving approach in PAUD institute

c. Policymaker

The policy of conducting early childhood education curriculum as guidance and instructional organization should be reviewed for improvement in accordance with the prevailing curriculum of early childhood by prioritizing the ability to solve the problem and think critically early on.

d. Parents

The application of problem solving approach can also be done in the family environment, but in ways that must be adjusted to the age and level of child development. The existence of prologue in the application of problem solving approach is something that is essential and must be understood by parents, so that the use of this approach does not bring stress to the child..

e. For further researchers

Considering that this action research is only focused on improving the mathematical ability of the beginning, especially covering aspects; classification, sequencing, matching, geometry, number concepts and number operations through problem solving approach, then for the next researcher still open the opportunity to be able to use problem solving approach in improving early math ability on other aspect or in improving ability of early child with variable other.

\section{References}

[1] A. Hopkins, Teacher's Guide to Classroom Research. Bristol: Open University Press, 1993.

[2] L. J. Moleong, Action Reach. Jakarta: PPS Unibersitas Negeri Jakarta, 2003.

[3] J. Greenberg and R. A. Baron, Behavior in Organization. New York: Prentice Hill International, Inc, 1995.

[4] E. Essa, Introcuction to Early Childhood Education. Belmont USA: Wadsworth Cengage Learning, 2011.

[5] S. Feeney, D. Christensen, and E. Moravcik, Who Am I in the Lives of Children. Pearson Education, Inc., 2006.

[6] J. A. Brewer, Early Childhood Education, Preschool Through Primary Grades. Boston: Pearson Education, Inc., 2007.

[7] J. Martini, Kesulitan Belajar Perspektif, Assesmen Dan Penanggulangannya. Jakarta: Yayasan Penamas Murni, 2009.

[8] Susan Sperry Smith, Early Chilhood Mathematics. United States of America: Pearson Education, Inc., 2009.

[9] Sumardyono, "Pengertian Dasar Problem Solving," 2013. [Online]. Available:

http://p4tkmatematika.org/file/problemsolving/PengertianDasarProbl emSolving_smd.pdf.

[10] S. Wina, Pendekatan Dalam Pembelajaran. Jakarta: Kencana Prenada Media Graup, 2003.

[11] Jean McNif, Action Research, Principles and Practice. London: Routledge, 1992. 